\title{
Response of Arbuscular Mycorrhizal Fungi and Soil Chemical Properties to Brachiaria decumbens Grass Production Technologies
}

\author{
Amanda Silva Parra ${ }^{*}$ \\ https://orcid.org/0000-0001-9872-790X
}

\section{Angela María Mogollón Ortiz ${ }^{1}$}

https://orcid.org/0000-0002-7741-0361

\section{Hernando Delgado Huertas ${ }^{1}$}

https://orcid.org/0000-0003-2627-7174

${ }^{1}$ Llanos University, Faculty of Agricultural Sciences and Natural Resources, Research Group on Innovation in Agricultural and Forest Systems, Villavicencio, Colombia.

\section{Editor-in-Chief: Paulo Vitor Farago}

Associate Editor: Adriel Ferreira da Fonseca

Received: 2019.05.23; Accepted: 2020.09.10.

*Correspondence: asilvap@unillanos.edu.co; Tel.: +57-314-8005493 (A.S.P.)

\section{HIGHLIGHTS}

- Brachiaria decumbens pasture associated with kudzu Pueraria phaseloides legume represents an alternative for higher arbuscular mycorrhizal fungi (AMF).

- Higher lime doses presented high rates of AMF and improved soil chemical properties (SCP).

- Higher lime doses were the most influential technological factor than the type of pasture and the $\mathrm{N}$, $\mathrm{P}, \mathrm{K}$ fertilizer sources on AMF.

Abstract: In order to improve the sustainability of livestock systems at Cumaral, Meta, under tropical conditions of Colombia, implementation of different Brachiaria decumbens production technologies can be beneficial for a better soil fertility. This study aimed to evaluate the effects of two pastures type (Factor A): (a) Brachiaria decumbens grass (B1) and Brachiaria decumbens grass associated with kudzu Pueraria phaseloides legume (B2); (b) Factor B: Four lime $\left(\mathrm{CaCO}_{3}\right)$ doses: $L 0=0$ tons ha-1, $L 1=1.1$ tons ha-1, $L 2=$ 2.2 tons ha- ${ }^{-1}$ and L3 $=3.3$ tons ha ${ }^{-1}$; and (c) Factor C: three N, P, K fertilizers sources: $100 \mathrm{~kg} \mathrm{ha}^{-1}$ Urea, 200 $\mathrm{kg} \mathrm{ha}^{-1}$ triple superphosphate (TSP) and $100 \mathrm{~kg} \mathrm{ha}^{-1}$ potassium chloride (PCl) on arbuscular mycorrhizal fungi (AMF) and soil chemical properties (SCP). Cluster analysis showed that B2*L3, L2*Urea, TSP, PCl increased the number of AMF spores per $g$ soil and improved soil chemical properties (SCP), as B1*L3*Urea, TSP, $\mathrm{PCl}$, in cluster 1 , higher lime doses were the most influential factor, indistinctly pasture type, as $\mathrm{N}, \mathrm{P}, \mathrm{K}$ fertilizer sources showed low effect in cluster conformation. Farmers in the area can implement these $B$. decumbens technological practices that help improve the sustainability of livestock systems at tropical zones. 
Keywords: fertilizers; lime; soil fertility; soil biology; technology.

\section{INTRODUCTION}

Arbuscular mycorrhizal fungi conservation at tropical soils is a priority, since most of the improved pastures of Brachiaria decumbens in acid soils are of very low soil biology and fertility (SBF), mainly phosphorus $(\mathrm{P})$. Acid soil limit pasture growth, yield and quality, reduce availability of such nutrients as $\mathrm{P}$, permit elements such as $\mathrm{Mn}, \mathrm{Fe}$ and Al that can be toxic for plants [1]. In tropical pastures, such an integrated soil fertility a number of innovative and efficient agricultural technologies has been adopted.

The inclusion of production technologies as legumes on pastures is an important alternative to improve soil nutrient availability and its absorption by plants that improve pasture yields [2]. Pasture $P$ nutrition, with emphasis on legume may be affected positively in response to a positive consequence on arbuscular mycorrhizal fungi (AMF) number [3]. Furthermore, Costa and coauthors [4] hypothesized that Pueraria phaseloides-AMF integration could be involved in soil nutrient bioavailability. This more rational alternative management of both the pasture-legume association and the action of the AMF, can guarantee the sustainability of livestock systems [5], legume-type forage plants are probably better adapted to a low availability of soil $\mathrm{P}$, developing high efficiency in the use of this nutrient, through mechanisms that until now are not very clear.

Legumes in the pastures fix nitrogen $(N)$ and the rhizobacteria have a marked influence on the formation and the functioning of AMF [6], considering the high costs of $\mathrm{N}$ fertilizers [7], it is a viable option to improve pasture conditions. In agricultural systems, Herridge and coauthors [2], reported biological nitrogen fixation (BNF) to be of $227 \mathrm{~kg} \mathrm{~N} \mathrm{ha}^{-1}$ annually for legume crops. Mycorrhizal symbiosis in legumes markedly increases the absorption of soil nutrients such as $\mathrm{N}, \mathrm{K}$, calcium (Ca), magnesium (Mg) and $\mathrm{P}$ especially [8], improves the transport and absorption of water in the pasture.

On the other hand, Aluminium (Al) toxicity is considered the main limiting factor for pastures growth on acid soils [1]. Liming of acid soils as technological strategie is the most adequate way to reduce their available Al contents; since the increase in $\mathrm{pH}$ can have adverse effects on the infectivity of native fungi that are adapted to acid soil conditions [9], which can reduce the formation of AMF [10]. Improvement of the $\mathrm{pH}$ and nutritional content of the soil are related to an increase in the density of AMF spores [11]. The pH level affects the number of spores of AMF because a slight increase in this level changes affect soil nutrients [3]. In Oxisoils the levels of available nutrients are not only depleted, but the soils contain no appreciable minerals reserves de $\mathrm{Ca}, \mathrm{Mg}, \mathrm{K}$ to be released, however, through of liming practice, the $\mathrm{Ca}$ and other soil bases can be improved [1].

The effect of fertilizers as other technological agricultural practice on AMF and soil chemical properties (SCP) should be tested, since very little has been investigated in tropical soils. According to Zhong and coauthors [12], high doses of mineral fertilization can inhibit the functioning of AMF; by contrast low doses of mineral fertilizers increased mycorrhizal colonization and crop yield [13]. According to Szanser and coauthors (2011), the addition of $\mathrm{N}$ can inhibit the colonization of AMF in some species of cultivated plants, its depressive effect being greater than that of $P$. However, fertilization experiments have shown that N, $P$, and potassium (K) all may limit soil microbial processes to some extent [14,15]. In many of tropical pasture sites, strong limitation of $\mathrm{N}$ and $\mathrm{P}$ together has been demonstrated. Gómez-Carabalí and coauthors [16] indicated that the introduction of grasses and legumes adapted to acidic and nutrient-poor soils, and the supplement of $P$ with low amounts of fertilizer, can help the restoration of degraded sites, increasing the amount of AMF.

According to the above described, the objective of this research work was to evaluate the effect of different technological practices associated to pasture of Brachiaria decumbens grass in order to maximize the number of AMF, improving soil chemical properties, contributing for a more sustainable livestock production at tropical zone of Cumaral, Meta department, East of Colombia.

\section{MATERIAL AND METHODS}

\section{Site description}

The study was conducted during September 2017 to September 2018, out in a field experiment established in pastures of Brachiaria decumbens grass at Cumaral city, Meta Department Piedmonts, East

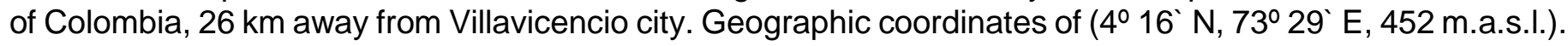
Average temperature of $21^{\circ} \mathrm{C}$. It has a cattle herd of about 52,300 cattle animals. This experiment was 
conducted during one year on tropical pastures and soil conditions. The topography corresponds to a flat plain and the soil is classified as Oxisoil (Jaramillo, 2002).

\section{Initial soil conditions}

Initial soil analysis (0-20 cm depth) indicated that soil acidity limited the capacity of the soil to supply nutrients. Description of soil properties showed extremely acid soil, such as a low pH (4.5), a low total Ca, $\mathrm{Mg}, \mathrm{K}$ contents $\left(2.0,1.3,0.2 \mathrm{cmol}_{\mathrm{c}} \mathrm{kg}^{-1}\right)$ respectively, a high $\mathrm{Al}$ concentration $\left(3.1 \mathrm{cmol}_{\mathrm{c}} \mathrm{kg}^{-1}\right)$ and a low available $\mathrm{P}\left(2.0 \mathrm{mg} \mathrm{kg}^{-1}\right)$. In these soils, $\mathrm{P}$ contents are particularly low and range from 3 to $5 \mathrm{mg} \mathrm{kg}^{-1}$ [17].

\section{Treatments and statistical design}

A complete block design at random was applied in a factorial $(2 \times 4 \times 3)$ arrangement and three repetitions, for a total of 72 experimental units. Each experimental area was $20 \mathrm{~m}^{2}(4 \mathrm{~m} \times 5 \mathrm{~m})$, for a total experimental area of $1,440 \mathrm{~m}^{2}$. For the purposes of soil sampling, a useful area of $12 \mathrm{~m}^{2}(3 \times 4 \mathrm{~m})$ was considered, to avoid the effect of borders.

The technological factors evaluated were: (a) two type of pasture (Factor $A$ ), that corresponded to pasture of $B$. decumbens grass (B1) of more than 10 years and pasture of $B$. decumbens pasture grass associated with Kudzú $P$. phaseloides leguminous (B2) of 2 years, the renewal of the legume on pasture is done every six months, sowing the legume with a pasture renovator; (b) four lime doses (Factor B) were estimated according to initial soil analysis, which is calculated as follows, as previously described by Cochrane and coauthors [18].

$$
\text { Lime }\left(\mathrm{CaCO}_{3}\right) \text { doses }(\text { ton ha-1) }=1.8 \times(\mathrm{Al}-(\mathrm{CAS}(\mathrm{ECEC})) / 100)
$$

Where lime doses is the amount of calcium carbonate $\mathrm{CaCO}_{3}$ (tons ha ${ }^{-1}$ ); 1.8 is a constant adapted for account the result in tons ha ${ }^{-1}$. $A l$ is exchangeable soil aluminum $\left(\mathrm{cmol}_{\mathrm{c}} \mathrm{kg}^{-1}\right)$; CAS is critical aluminum saturation Als that can tolerate pasture (35\%) under tropical conditions, ECEC is effective cation exchange capacity $\left(\mathrm{cmol}_{\mathrm{C}} \mathrm{kg}^{-1}\right)$, which is the sum of exchangeable bases $(\mathrm{Al}, \mathrm{Ca}, \mathrm{Mg}, \mathrm{K})$, using potassium chloride $1 \mathrm{M}$ as extractant by $\mathrm{Al}$ and ammonium acetate $1 \mathrm{M}$ at $\mathrm{pH} 7.0$ by $\mathrm{Ca}, \mathrm{Mg}, \mathrm{K}$ bases.

When Als of exchange capacity exceeds $60 \%$, appreciable amounts of Al start to get into the soil solution, at this point plant Al toxicity, caused by soil acidity, can occur [17].

Cochrane and coauthors [18] proposed that the liming requirements of acidic soils be estimated in terms of a target level of $\mathrm{Al}$ saturation. Based on these concepts and data, the treatments of lime $\left(\mathrm{CaCO}_{3}\right)(\mathrm{Factor}$ $B$ ) is defined as follows: 0 tons ha ${ }^{-1}$ (L0), 1/3 recommended lime dose accounting for 1.1 tons ha ${ }^{-1}$ (L1), 2/3 recommended lime dose accounting for 2.2 tons ha ${ }^{-1}$ (L2), 3/3 recommended lime dose accounting for 3.3 tons $\mathrm{ha}^{-1}$ (L3), through broadcast application on pastures already established; (c) factor $\mathrm{C}$ corresponded to three N, P, K fertilizers sources: $100 \mathrm{~kg} \mathrm{ha}^{-1}$ of Urea (Urea), $200 \mathrm{~kg} \mathrm{ha}^{-1}$ of triple superphosphate (TSP), 100 $\mathrm{kg} \mathrm{ha}^{-1}$ of potassium chloride (PCl) [19], through total applications together with the practice of the application of lime, which was before the first cut, each cut of 45 days, and the variables were evaluated after the third cut.

\section{Field experiment management}

This field has been under 0.5 tons ha- of $\mathrm{CaCO}_{3}$ and $100 \mathrm{~kg} \mathrm{ha}^{-1}$ of complete NPK fertilizer conditions. The treatments were applied only once at the beginning of the experiment, remaining height of pastures at sampling was approximately $5 \mathrm{~cm}$, obtained through simulated grazing. The experimental units were monitored during the following twelve months, the pastures were grown using standard recommended practices for extensive pastures at Cumaral. An integral management of pests and diseases was carried out.

\section{Field sampling and soil chemical analysis}

Before starting the experiment, a soil sample composed of three points taken at random in an area of $720 \mathrm{~m}^{2}$ was extracted and a complete chemical analysis was carried out in order to define the lime dose treatments. In each of the experimental units a sample composed of three points was extracted at a depth of $0.20 \mathrm{~m}$, to make SCP determinations using standard analytical procedures of Jaramillo [17]. The measurements were made a year after the trial was established, after the fourth cut, each cut three months [19].

The most important soil chemical properties from this analysis were $\mathrm{pH}$ by the potentiometric method soil: water (1:1); available soil $\mathrm{P}(\mathrm{mg} / \mathrm{kg})$ by the Bray II method with $\mathrm{NH}_{4} \mathrm{~F} 0.03 \mathrm{~N}$; exchangeable aluminum 
(Al) $\left(\mathrm{cmol}_{\mathrm{c}} \mathrm{kg}^{-1}\right)$ by $\mathrm{PCl}$-extractable cations $1 \mathrm{~N}$; and soil bases $\mathrm{Ca}, \mathrm{Mg}, \mathrm{K}$ contents $\left(\mathrm{cmol}_{\mathrm{c}} \mathrm{kg}^{-1}\right)$ with $\mathrm{NH}_{4} \mathrm{OAc}$ $1 \mathrm{M}$ extraction. The effective cation exchange capacity (ECEC) was obtained from the arithmetic sum of the concentrations of the exchangeable $\mathrm{Ca}, \mathrm{Mg}, \mathrm{K}$ and $\mathrm{Al}$ cations, whereas $\mathrm{Al} / \mathrm{ECEC}$ was multiplied by 100 to obtain the exchangeable Al saturation (Als). Bases sum levels $(\mathrm{V})\left(\mathrm{cmol}_{\mathrm{c}} \mathrm{kg}^{-1}\right)$ is the sum of $\mathrm{Ca}, \mathrm{Mg}, \mathrm{K}$. The critical ranges for the soil's elements were evaluated according to Guerrero [19].

\section{Extraction and counting number of AMF spores}

A laboratory trial was conducted at Phytopathology Laboratory of the Faculty of Agricultural Sciences and Natural Resources at University of the Llanos, the extraction of spores of arbuscular mycorrhizal fungi (AMF) was performed by the sieving method in aqueous solution applied by Soteras and coauthors [20]. 100 $\mathrm{g}$ of soil were passed through sieves of 500,200 and $38 \mu \mathrm{m}$ and thoroughly washed with distilled water, and the soil fraction between 500 and $200 \mu \mathrm{m}$ was distributed onto plastic tubes. $25 \mathrm{~mL}$ of the spore suspensions were transferred to $50 \mathrm{~mL}$ centrifugation tubes. $25 \mathrm{~mL}$ of a $70 \%$ sugar solution (w/v) were added to the bottom of the tubes, and then the tubes were centrifuged at 2,000 rpm for $2 \mathrm{~min}$. Finally, after centrifugation, the samples were decanted, washed, and transferred to Petri dishes. Spores were carefully counted under the dissection microscope at up to 400 -fold magnification. The spores for count were grouped according to their morphological characteristics as color, shape, size and presence/absence of hyphae [20]. The abundance of AMF spores was expressed as number of spores per $\mathrm{g}$ of soil.

\section{Statistical analysis}

The data obtained in the field were analyzed statistically with the Infostat program (version 2017) and a oneway analysis of variance to evaluate the significant differences among means of all tested parameters at $99 \%$ level of confidence. Further statistical validity of the differences among treatment means were estimated using the Tukey's test at $95 \%$ level of confidence for analysis of simple and double factors. The triple interactions between factors were analyzed through multivariate analysis to shape cluster, using Euclidean distances.

\section{RESULTS}

The analysis of variance indicated highly significant differences for type of pasture, lime dose for all the variables analyzed, except for the $\mathrm{N}, \mathrm{P}, \mathrm{K}$ fertilizer sources, while, the interaction of lime doses* $\mathrm{N}, \mathrm{P}, \mathrm{K}$ fertilizer sources showed highly significant differences only for AMF and available soil $P$, in this sense, only these responses were analyzed using tukey tests at 95\% probability, on the other hand, analysis of variance showed that all triple interactions were highly significant for the variables analyzed, and were analyzed using cluster analysis.

\section{Effect of pasture type on arbuscular mycorrhizal fungi and soil chemical properties}

Numbers of spores of arbuscular mycorrhizal fungi and soil chemical properties were significantly affected by pasture type technology (factor A), providing B1 the lower AMF abundance (8 spores per $g$ of soil), while the highest abundance was recorded in B2 (13 spores per g of soil) $(P<0.05)$ (Table 1). Greater conservation of AMF in $\mathrm{B} 2$ was associated with increases in $\mathrm{pH}$, exchangeable bases $(\mathrm{Ca}, \mathrm{Mg}, \mathrm{K})$, ECEC and $\mathrm{V}$, less exchangeable $\mathrm{Al}$ and Als that decreased, showing significant differences with $\mathrm{B} 1(P<0.05)$ (Table 1). 
Table 1. The effect of pasture type technology on the abundance of arbuscular mycorrhizal fungi and soil chemical properties. Averages followed by the same letter indicate no significance by Tukey test $(p<0.05)$.

Soil chemical properties ${ }^{b}$

\begin{tabular}{|c|c|c|c|c|c|c|c|c|c|c|}
\hline & AMF & $\mathrm{pH}$ & $\mathrm{Ca}$ & Mg & $\mathbf{K}$ & Al & ECEC & Als & $\mathbf{V}$ & $\mathbf{P}$ \\
\hline Pasture Type & $\begin{array}{l}\text { Spore per } \\
\mathrm{g} \text { of soil }\end{array}$ & & ---- & $-----c m$ & $\mathrm{Ol}_{\mathrm{c}} \mathbf{k g}^{-}$ & י--נ-י-ר. & & ---.. & 6---- & $\mathrm{mg} \mathrm{kg}^{-1}$ \\
\hline $\begin{array}{l}\text { B1 } \\
\text { B2 }\end{array}$ & $\begin{array}{l}8 a \\
13 b\end{array}$ & $\begin{array}{l}4.5 a \\
4.7 b\end{array}$ & $\begin{array}{l}2.0 \mathrm{a} \\
3.0 \mathrm{~b}\end{array}$ & $\begin{array}{l}1.7 a \\
2.5 a\end{array}$ & $\begin{array}{l}0.3 a \\
0.4 b\end{array}$ & $\begin{array}{l}1.9 \mathrm{~b} \\
1.4 \mathrm{a}\end{array}$ & $\begin{array}{l}6.3 a \\
7.4 b\end{array}$ & $\begin{array}{l}30 \mathrm{~b} \\
20 \mathrm{a}\end{array}$ & $\begin{array}{l}4.4 a \\
6.0 \mathrm{~b}\end{array}$ & $\begin{array}{l}3.3 a \\
3.6 b\end{array}$ \\
\hline
\end{tabular}

${ }^{\mathrm{a}} \mathrm{B} 1=B$. decumbens grass; $\mathrm{B} 2=B$. decumbens grass associate with kudzu $P$. phaseloides forage. ${ }^{\mathrm{b}} \mathrm{AMF}=$ Arbuscular mycorrhizal fungi, ECEC = effective cation exchange capacity; Als = Aluminum saturation; $V=$ base sum level; $P=$ phosphorus available.

\section{Effect of lime doses on arbuscular mycorrhizal fungi and soil chemical properties}

In Table 2, the relative number of spores of AMF and SCP for $\mathrm{pH}$, exchangeable soil bases $(\mathrm{Ca}, \mathrm{Mg}, \mathrm{K})$, ECEC and $V$ increased with highest lime doses, that did not showed differences between them, but if with the lowest doses of lime, which showed low effect $(P<0.05)$. Effect of higher lime L3 doses on AMF could be improved by up to $126.8 \%$ compared with L0, which increased $V$ by $82.8 \%$, decreasing the exchangeable $\mathrm{Al}$ and Als (averages of 2.8 to $0.8 \mathrm{cmol}_{\mathrm{c}} \mathrm{kg}^{-1}$ and 43 to $10 \%$ ), respectively (Table 2). The increases of lime doses as technological practice also exerted a significant effect on the available soil $\mathrm{P}$ ( $\mathrm{P}$-Bray), this was increased from 2.0 to $5.1 \mathrm{mg} \mathrm{kg}^{-1}$ with no lime L0 compared to L3 respectively $(P<0.05)$ (Table 2$)$.

Table 2. Effect of different doses of lime technologies on the abundance of AMF (No. of spores per $g$ of soil) and soil chemical properties (SCP). Averages followed by the same letter indicate no significance by Tukey test $(p<0.05)$.

\begin{tabular}{|c|c|c|c|c|c|c|c|c|c|c|}
\hline \multirow{3}{*}{ Lime doses $^{a}$} & \multirow{2}{*}{ AMF } & \multicolumn{9}{|c|}{ Soil chemical properties ${ }^{b}$} \\
\hline & & pH & $\mathrm{Ca}$ & Mg & K & Al & ECEC & Als & V & $\mathbf{P}$ \\
\hline & \multicolumn{2}{|l|}{$\begin{array}{l}\text { spores } \\
\text { per } g \text { of } \\
\text { soil }\end{array}$} & \multicolumn{5}{|c|}{-----------cmolc kg ${ }^{-1}$} & \multicolumn{2}{|c|}{--------\%----- } & $\mathrm{mg} \mathrm{kg}^{-1}$ \\
\hline LO & $6.2 \mathrm{~b}$ & $4.2 \mathrm{~b}$ & $2.0 \mathrm{~b}$ & $1.5 b$ & $0.2 b$ & $2.8 \mathrm{a}$ & $6.5 b$ & $43.0 \mathrm{a}$ & $3.8 b$ & $2.0 \mathrm{~b}$ \\
\hline L1 & $9.0 \mathrm{~b}$ & $4.4 b$ & $2.3 b$ & $1.7 \mathrm{~b}$ & $0.3 b$ & $1.8 \mathrm{a}$ & $6.2 \mathrm{~b}$ & $31.0 \mathrm{a}$ & $4.4 \mathrm{~b}$ & $2.6 b$ \\
\hline L2 & $12.0 \mathrm{a}$ & $4.8 a$ & $3.1 a$ & $2.2 \mathrm{a}$ & $0.4 a$ & $1.2 \mathrm{~b}$ & $7.0 \mathrm{a}$ & $17.0 \mathrm{~b}$ & $5.9 a$ & $3.9 a$ \\
\hline L3 & $14.0 \mathrm{a}$ & $5.1 \mathrm{a}$ & $3.5 a$ & $2.9 a$ & $0.5 a$ & $0.8 \mathrm{~b}$ & $7.7 \mathrm{a}$ & $10.0 \mathrm{~b}$ & $6.9 a$ & $5.1 \mathrm{a}$ \\
\hline
\end{tabular}

a Lime $\left(\mathrm{CaCO}_{3}\right)$ doses: $\mathrm{LO}=0$ tons ha ${ }^{-1}, \mathrm{~L} 1=1.1$ tons ha ${ }^{-1}$, L2 = 2.2 tons ha ${ }^{-1}$, L3 = 3.3 tons ha ${ }^{-1}$;

${ }^{\mathrm{b}} \mathrm{AMF}=$ Arbuscular mycorrhizal fungi, ECEC = effective cation exchange capacity, Als = aluminum saturation percentage, $\mathrm{V}=$ base sum level, $\mathrm{P}$ = phosphorus available.

\section{Interaction lime doses $x$ N, P, K fertilizers sources technologies on arbuscular mycorrhizal fungi and available soil phosphorus}

As shown in Figure 1, number of AMF spores and available soil $P$ were affected significantly by the interaction of lime $x$ N, P, K fertilizer sources. Figure 1 present, number of AMF spores (Figure $1 \mathrm{~A}$ ) that was significantly increased by L3, L2*Urea and available soil P (Figure $1 \mathrm{~B}$ ) by L3*Urea. In Figure $1 \mathrm{~A}$, number of AMF spores was 10 and $20 \%$ highest in Urea $(P<0.05)$ compared to TSP and PCI respectively, that weren't significantly different $(P>0.05)$. In Figure $1 \mathrm{~B}, \mathrm{~L} 0^{*} \mathrm{PCl}$, TSP presented the lowest levels of available soil $\mathrm{P}$, which were not significant $(P>0.05)$. The results revealed significant increase in available soil $P$ with integrated approaches of $\mathrm{L}^{*}$ Urea compared to TSP and PCI $(P<0.05)$. Urea in all cases with lime doses exceeded $\mathrm{PCl}$ and TSP, except in L0, where Urea was equal to TSP $(P>0.05)$ (Figure $1 \mathrm{~B})$. 
(a)

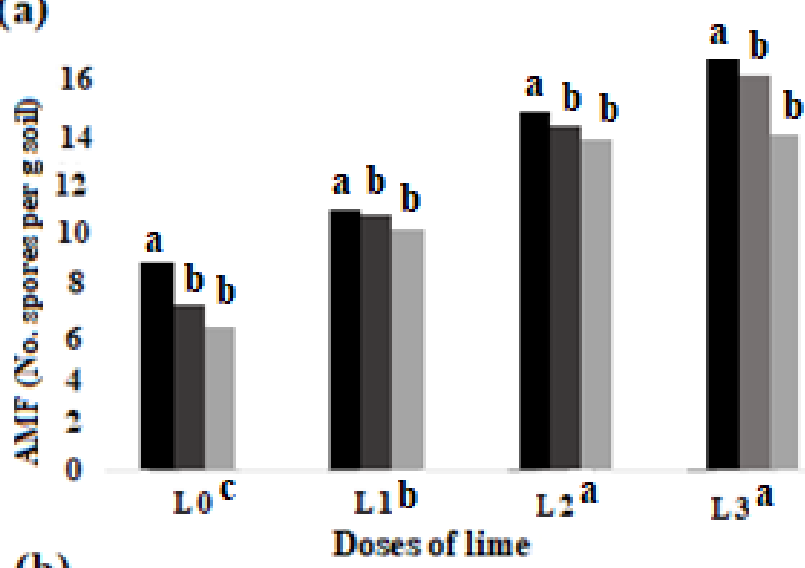

(b)

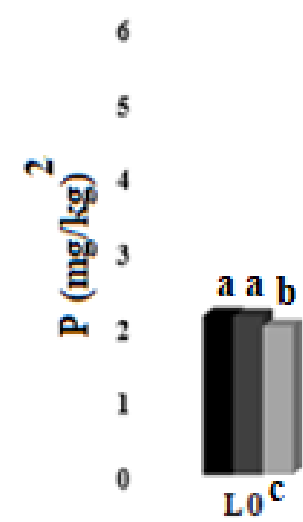

Doses of lime

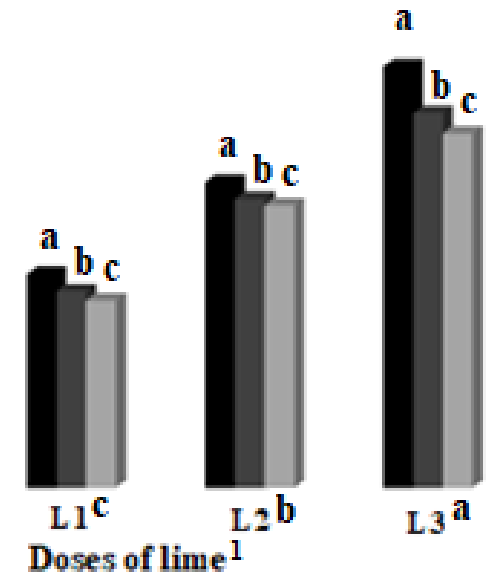

- Urea, $100 \mathrm{~kg} \mathrm{ha}^{-1}$

- TSP, triple superphosphate $200 \mathrm{~kg} \mathrm{ha}^{-1}$

-' PCl, Potassium chloride $100 \mathrm{~kg} \mathrm{ha}^{-1}$

Figure 1. Interaction of doses of lime $x \mathrm{~N}, \mathrm{P}, \mathrm{K}$ sources fertilizers on (a) soil available $\mathrm{P}$; and (b) AMF abundance.

${ }^{1} x$-asis is lime $\left(\mathrm{CaCO}_{3}\right)$ doses, $\mathrm{LO}=$ No lime (control) $\left(0\right.$ tons ha $\left.{ }^{-1}\right), \mathrm{L} 1=1 / 3$ recommended of lime dose $\left(1.1\right.$ tons ha $\left.{ }^{-1}\right), \mathrm{L} 2=2 / 3$ recommended of lime dose $\left(2.2\right.$ tons ha $\left.{ }^{-1}\right), L 3=3 / 3$ recommended of lime dose $\left(3.3\right.$ tons ha-1). ${ }^{2} y$-asis is $P\left(\mathrm{mg} \mathrm{kg}^{-1}\right)(\mathrm{Figure} 1 \mathrm{a})$, and AMF (No. spores per g soil) (Figure $1 \mathrm{~b}$ ). Averages followed by the same letter indicate no significance by Tukey test $(p<0.05)$.

Principal Component Analysis and Agglomerative Hierarchical Cluster Analysis of triple interaction: pasture type $x$ lime doses $x$ N, P, K fertilizers sources technologies on Arbuscular Mycorrhizal Fungi under different SCP

In order to examine the relationship between soil chemical properties and AMF and the agronomic factors adopted a principal components analysis was carried out principal component analysis (PCA) and the results are showed at the Table 3. In the PCA, PC1 and PC2 contributed $73 \%$ of variance among the variables observed in the study. The variables with the greatest contribution to $38 \%$ of the variance, expressed by the first principal component (PC1), were AMF, $\mathrm{pH}, \mathrm{Ca}, \mathrm{Mg}, \mathrm{ECEC}, \mathrm{V}$, available soil $\mathrm{P}$; as the inverse relationship of $\mathrm{Al}$ and ALs with the other variables were confirmed in cluster 1 conformation (Table 3, Figure 2). In PC2, which explain $35 \%$ of the variance, the variables with the greatest contribution and in a positive way that influence the separation of technological factor in cluster 2 were Als, ECEC and inversely soil pH (Table 3, Figure 2).

Table 3. Principal component analysis of arbuscular mycorrhizal fungi under different soil chemical properties.

\section{Soil chemical properties}

$\mathrm{PC}^{1}$

\section{Partial and cumulative variance contribution}

\begin{tabular}{lcccccccccccc} 
& AMF & pH & Ca & Mg & K & Al & ECEC & Als & V & P & (\%) \\
\hline PC 1 & 0.83 & 0.78 & $\mathbf{0 . 7 3}$ & 0.80 & 0.68 & $-\mathbf{0 . 8 4}$ & 0.83 & $-\mathbf{0 . 8 0}$ & 0.99 & $\mathbf{0 . 8 8}$ & 38 & 38 \\
PC 2 & $\mathbf{0 . 0 9}$ & $-\mathbf{0 . 7 0}$ & 0.06 & 0.16 & 0.21 & 0.37 & $\mathbf{0 . 7 0}$ & $\mathbf{0 . 7 0}$ & 0.14 & -0.17 & 35 & 73 \\
\hline
\end{tabular}

${ }^{1} \mathrm{PC}=$ Principal component, $\mathrm{ECEC}=$ effective cation exchange capacity; Als = Aluminum saturation; $\mathrm{V}=$ base sum level; $\mathrm{P}=$ available soil $\mathrm{P}$. Values $>0.7$ (absolute value) appear in bold. 
Figure 2 represents the dendrogram for cluster analysis based on the similarity of the number of AMF spores under different SCP by technological factors of $B$. decumbens pasture analysed which formed two large groups, i.e., I, II using the Euclidean method. The first large (Cluster I) group was formed by 9 technological factors, i.e., B2* ${ }^{*} 3 /$ or $\mathrm{L} 2{ }^{*}$ Urea/or TSP/or $\mathrm{PCl}$ fertilizers sources like $\mathrm{B} 1{ }^{*} \mathrm{~L} 3{ }^{*} \mathrm{~N}, \mathrm{P}, \mathrm{K}$ fertilizers sources (Figure 2). Cluster II grouped 15 technological factors, there were non-significant differences between $\mathrm{B} 2$ and $\mathrm{B} 1{ }^{*} \mathrm{~L} 0 /$ or $\mathrm{L} 1{ }^{*}$ Urea/or TSP/or PCl fertilizer sources on number of AMF spores. Hence, it is found again that pasture type and N, P, K fertilizer sources were less influential factors on AMF, which indicated that cluster conformation the most influential factor was lime doses. The results in cluster 2 , showed that lower lime doses are close to complying with lower SCP regulations on AMF, which results in a limited effect of the implementation of these technological practices for best $B$. decumbens pastures management.

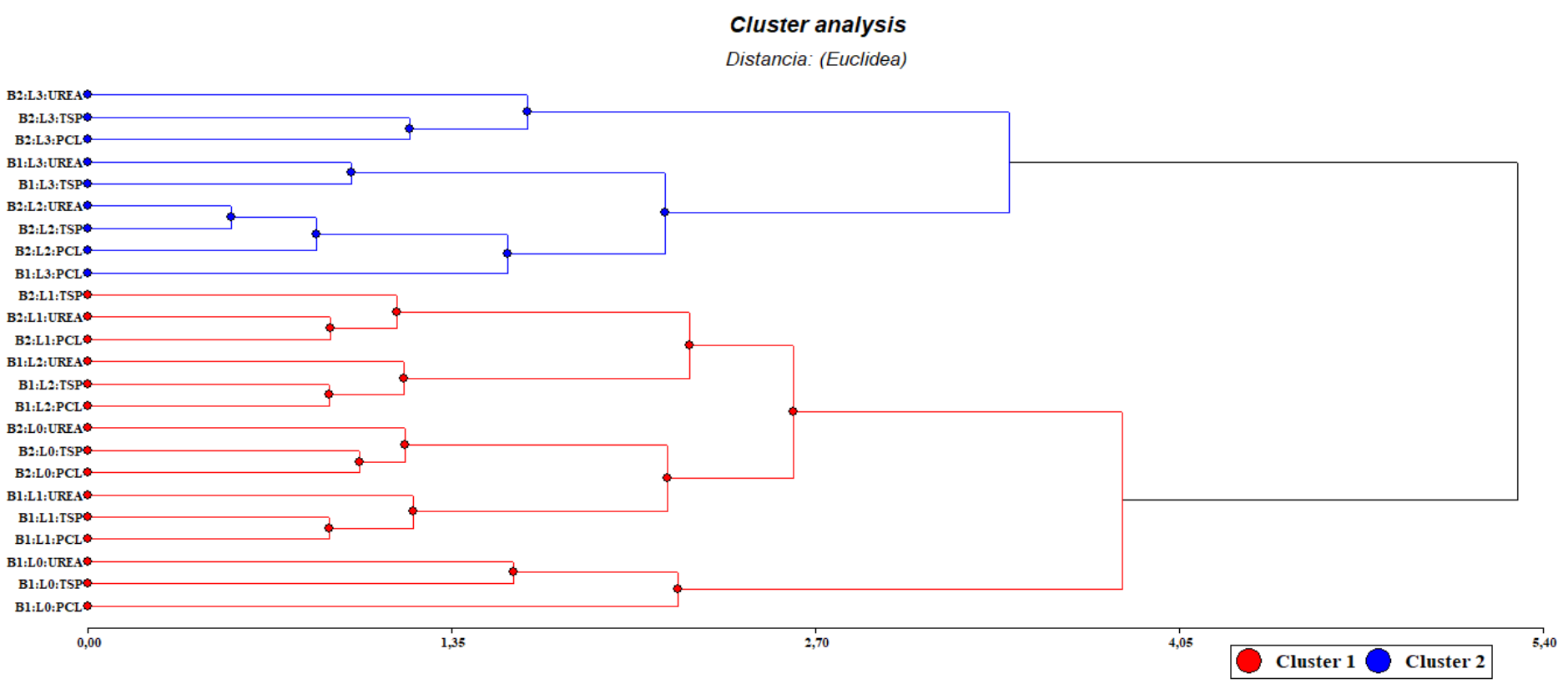

Figure 2. Cluster analysis (Euclidean distance) of the 24 interactions between pasture type $x$ lime dose $x \mathrm{~N}, \mathrm{P}$, and $\mathrm{K}$ fertilizer source on AMF and soil chemical properties.

$\mathrm{B} 1=B$. decumbens grass; $\mathrm{B} 2=B$. decumbens grass associated with $P$. phaseloides forage

$L 0=$ No lime (control) $(0 \mathrm{t} / \mathrm{ha}) ; \mathrm{L} 1=1 / 3$ recommended of lime $\left(\mathrm{CaCO}_{3}\right)$ dose $\left(1.1\right.$ ton ha $\left.{ }^{-1}\right) ; \mathrm{L} 2=2 / 3$ recommended of lime dose $\left(2.2\right.$ tons $\left.\mathrm{ha}^{-1}\right) ; \mathrm{L} 3=3 / 3$ recommended of lime dose $\left(3.3\right.$ tons ha $\left.{ }^{-1}\right)$

Urea $=100 \mathrm{~kg} \mathrm{ha}^{-1} ; \mathrm{TSP}=$ triple superphosphate $200 \mathrm{~kg} \mathrm{ha}^{-1} ; \mathrm{PCl}=$ potassium chloride $100 \mathrm{~kg} \mathrm{ha}^{-1}$

Significant difference $(p<0.05)$.

\section{DISCUSSION}

\section{Effect of pasture type on Arbuscular Mycorrhizal Fungi and Soil Chemical Properties}

It is possible that the best response of B2 by the influence of legume in a grass pasture could also be due to higher SCP improve, which influenced greater on AMF abundance. However, according to the critical ranges by Guerrero [19], the results of SCP remain very low, except Mg. Studying the effect of type of pasture on arbuscular mycorrhizal fungi and soil chemical properties, species and varieties of pasture may differ in the AMF sporulation due to genetic factors related to root morphology, the rate of absorption of nutrients, the habit of growth and the influence of abiotic factors [20,21].

The radical morphology of pasture type is relate to the degree of mycorrhizal association and the ability to absorb nutrients [3]. Another effect of AMF on legumes is in the symbiosis tripartite with bacteria of the genus Rhizobium. The symbiosis with the bacteria provides for $\mathrm{N}$ fixed biologically (NFB), while the AMF increase the absorption of $\mathrm{P}$, legumes provide bacteria and the contribution of AMF for the bacteria is photosynthates [22,23]., which also explains the better response of B2 compared to B1 on AMF. Martin and Rivera [24], has found a positive effect of legumes on the content of exchangeable cations and available soil $P$. Richardson and coauthors [25], state that the percentage of AMF colonization in tropical forage legumes varies from 3 to $41 \%$, which would indicate the ability of these species to maintain AMF populations. In accordance to our results AMF abundance was consistently stimulated by pasture type, which can be explained by Gonzales and coauthors [26]; Spagnoletti and coauthors [23]. 
The present study facilitated to determine that B2 produced a better effect on AMF and SCP as found by Fabrice and coauthors [27], due possibly to that legume in pasture can to increase root system and soil organic matter SOM, the increase in soil nutrients is an aspect of great interest to measure the effectiveness of the AMF symbiosis in the pasture, since the AMF can improve the absorption capacity of the roots and mobilize the P from the deepest levels of the soil. Soil microorganisms are vital constituents of the rhizosphere and they play key roles in P cycling [8]. Tajini and coauthors [28] showed as Glomus intraradices and Rhizobium tropiciCIAT899 increased $\mathrm{P}$ use efficiency for $\mathrm{N}_{2}$ fixation in the common bean (Phaseolus vulgaris L.) under $P$ deficiency in hydroaeroponic culture.

Frankow-Lindberg and Dahlin [29] indícate beneficial interaction of legume on $\mathrm{N}_{2}$ fixation, $\mathrm{N}$ transfer, and yield in grassland communities. Similarly, Martin and Rivera [24], also showed beneficial influence of legume on the main corn crop. Nitrogen transfer between a legume and accompanying grass species via arbuscular mycorrhizal fungal hyphae has been demonstrated by Lüscher and coauthors [5], legume plants had higher infection rates than grass. Hence, the fastest mineralization induced by legumes, significant higher amounts of $\mathrm{N}$ and other nutrients that can are soil release, which also can favor AMF.

Reduction of mineral fertilizers with improve in the efficiency for legume on pasture, varies in the ranges of $25-60 \%$ [30], and leads, increases in the coefficients of use of these, as well as to a decrease in the critical indexes of the elements in the soil [19], as also to reduce GHG emissions to the atmosphere. The potential to incorporate the management of AMF to maximize pasture $P$ use efficiency has been highlighted by crisis in available soil $P$ reserves [11], for instance, advances in symbiotic interactions of beneficial AMF on pastures have led to the development of livestock systems at tropical zones of world. However, the benefit is broader and more complex, indicating that mycorrhizal interaction of legume and pastures can tolerate adverse environments, biotic and abiotic, as tolerance to the exchangeable soil Al [31], as was shown with respect to the effect of $B 2$ to achieve the lowest Als content.

According to $\mathrm{Wu}$ and coauthors [32], external mycelium of the AMF produces low molecular weight exudates or glomalin, and the heavy metal bio-absorption by the fungal hypha could be modulating the interactions between plants and soil Al. It is considered that the degree of toxicity by Al varies widely depending on the species of grasses, growth conditions, Al concentrations and exposure time [1]. According to Seguel and coauthors [33], AMF colonization of plants increases the demand and influx of C fixation to the root cells, in turn the AMF increase the uptake of $P$, to which they transfer it to the host plant covering the possible limitations of $\mathrm{P}$ that can generated by the presence of $\mathrm{Al}$ in the rhizosphere, also stimulating the process of $\mathrm{C}$ in the roots, which results in the increase and availability of organic acids and other substrates of $\mathrm{C}$ for exudation, which in turn trap the exchangeable $\mathrm{Al}$ in the area of the rhizosphere. Hence, other explanation is that AMF is more sensitive to all the changes that take place in the legume-grass mycorrhizosphere as production of exudates and $\mathrm{pH}$ changes, which lead to $\mathrm{Al}$ chelation and retention, favoring SCP conditions in B2 compared with B1.

Longo and coauthors [34], working with mucuna legume and bean guandul associated with Brachiaria humidícola, which were fertilized with NPK fertilizers, found SCP improvement. Pastures established under limiting conditions such as high acidity and low fertility of soils, higher levels of AMF colonization are associated with incorporation of legumes in pastures [11], generally with an increase in the acquisition of nutrients due to changes in exchangeable cations. According to Delgado and coauthors [35], four legumes used as improved fallows before rice and corn crops, increased $\mathrm{Ca}, \mathrm{Mg}, \mathrm{K}, \mathrm{P}, \mathrm{Zn}$ and SOM contents in an Inceptisoil at tropical zone of Colombia. AMF participation in the acquisition of $\mathrm{K}$ represents also an important way at tropical grassland; hence, $\mathrm{K}$ content was affected also positively by $\mathrm{B} 2$. Integrated legume-pasture are currently promoted agricultural production technology that aim to use better plant resources through production integration and intensification.

\section{Effect of lime doses on Arbuscular Mycorrhizal Fungi and Soil Chemical Properties}

Arbuscular mycorrhizal fungi and SCP were increased with L3 and L2 lime doses, liming is an effective and dominant practice to reduce the acidity of the soil which decrease the available of soil $\mathrm{Al}, \mathrm{Fe}, \mathrm{Mn}, \mathrm{Zn}$, and $\mathrm{Cu}$ contents, but increases the availability of other essential nutrients as $\mathrm{P}$ and soil bases [1]. The same authors suggest that the quantity of lime required depends on the soil type, quality of liming material, costs and crop species or cultivars. Result that was coincident with those found by Schneider and coauthors [10]. Theoretically, in tropical soils, soil acidity is quantified on the basis of soil Als [17]. According to Pérez and Fuentes [36], they found that based on the soil physical and SCP, the factors that best explain the phenomenon of sporulation of AMF-forming fungi associated with the rhizosphere of Colosoana grass were $\mathrm{pH}$ and $\mathrm{K}$; suggesting that the increased noted on AMF might be related to decreased Als. According to Pérez 
and Vertel [37], high percentages of AMF colonization occur with moderate contents of $\mathrm{P}\left(18.94 \mathrm{mg} \mathrm{kg}^{-1}\right), \mathrm{N}$ $(0.03 \%)$, very low values of $\mathrm{Na}\left(1.7 \mathrm{cmol}_{\mathrm{c}} \mathrm{kg}^{-1}\right)$ and $\mathrm{pH}$ mildly alkaline (7.8). The low availability of $\mathrm{P}$ in these soils and the excess of exchangeable Al limit the development and production of tropical pastures [25]. The result of this research also was coincided with those obtained by Adesemove and Kloepper [8] and Costa and coauthors [4]. While L2 also increases AMF abundance and SCP, it is recommended technological practice due to that the highest restrictions of high lime doses use on pasture production that is the increase in costs, and GHG emission to the atmosphere [38].

\section{Lime $x \mathbf{N}, \mathbf{P}, \mathrm{K}$ fertilizers sources interactions as practical technologies on Arbuscular Mycorrhizal Fungi and available soil $\mathbf{P}$}

Pasture production in tropical soils requires large amount of lime and chemical fertilizers, which enhance nutrient release and availability for grass and forage nutrition [3-30]. Fertilizer has a positive impact to soil nutrients content, because macro nutrients consists of $\mathrm{N}, \mathrm{P}$, and $\mathrm{K}$ that are necessary for pasture growth [19]. The results suggested that increasing lime doses was promoted by AMF and available soil $P$ in a dosedependent higher, due possibly to that the efficiency of $\mathrm{N}$ fertilization was improved by AMF, unlike sources with $\mathrm{P}$ and $\mathrm{K}$; however, according to the critical ranges by Guerrero [19], the available soil P contents is lower in all treatments evaluated. AMF-pasture symbiosis can help pasture growth in acid soil by enhancing better pasture nutrition [11]. Pastures in tropical soils are characterized by very low fertility. Szanser and coauthors [39] affirmed that the starvation of several nutrients, of nitrate $\mathrm{NO}_{3}^{-}$, has been shown to reverse the inhibitory effect of $\mathrm{P}$ on $\mathrm{AMF}$, promoting dominant AMF that counteracts the effects of high $\mathrm{P}$ levels. On the other hand, the effect of $\mathrm{N}$ fertilization may be overshadowed by $\mathrm{N}_{2} \mathrm{O}$ emissions to the atmosphere [30], although Bender and coauthors [40] suggests that AMF could regulate $\mathrm{N}_{2} \mathrm{O}$ emissions by enhancing plant $\mathrm{N}$ uptake and assimilation. Arbuscular mycorrhizal fungi and available soil $\mathrm{P}$ was adversely affected by $\mathrm{P}$ and $\mathrm{K}$ supply levels coinciding with the results obtained by Liu and coauthors [15]. Most fertilizer P applied to the soil is immobilized due to the strong adsorption of $\mathrm{P}$ to aluminum cations at low $\mathrm{pH}$ and calcium (Ca) [17], thus reduce $P$ availability and consequently efficiency of $P$ fertilizers. AMF exhibiting beneficial traits responsible for bio-solubilization of insoluble forms of $P$ are presumably needed in most agricultural soils [11], where $P$ use efficiency by pasture can be improve with liming practice at tropical soils [1].

\section{Cluster analysis of triple interaction (pasture type $x$ lime doses $x N, P, K$ fertilizers sources) as practical technologies on Arbuscular Mycorrhizal Fungi under different SCP}

Understanding the impact of technological factors of $B$. decumbens on soil chemical properties (SCP) is crucial to understanding arbuscular mycorrhizal fungi (AMF). The first group accounting $37.6 \%$ of the analyzed B2* L2, L3*Urea, TSP, PCl factors and similarity B1 with L3, which are characterized by higher levels of number of AMF spores, which showed higher $\mathrm{pH}$, soil bases, and available soil $\mathrm{P}$, and lower Als related to "improved SCP" indicating a greater contribution at PC1, compared with second group (cluster 2) that account $62.5 \%$ of the others analyzed factors, with higher interchangeable acidity and ECEC apporting to PC2 conformation related to "soil acidity".

On the other hand, cluster analysis showed that especially lime is the most limiting technological factor on AMF under different SCP, since its effect could be verified, being that type of pasture and N, P, K fertilizer sources influenced less. Liming can optimize the efficiency of fertilizer use, partially reducing the environmental impact [1]. Consequently, AMF-plant relationship is not considered specific, because any species of AMF can colonize or symbiosis any plant [41], since they are found in practically all types of soils. Different Brachiaria grass types are widely planted in the tropics for sustainable livestock production, proving its effectiveness in soil fertility, indistinctly if it is associated or not with legume. Even though all tested fertilizers influenced in the same way on AMF under different SCP in B2 and B1, result not were coincident with Schmidt and coauthors [42], they affirm that $P$ fertilizer to be the most important element in mycorrhizal regulation. Phosphorus fertilization has been shown to affect $N$ uptake and $N$ use efficiency [13]. Nouri and coauthors [43] suggested that AMF regulation depends on the complex's interactions of soil nutrients pathways. The results obtained also make it possible to ensure that the efficiency of using N, P, K fertilizers is improved through of liming practice, acting in a similar way at SCP improve at tropical zones. 


\section{CONCLUSIONS}

The present investigation allowed to distinguish how B2 and highest lime doses as a technological practice allows to improve the SCP, influencing a greater number of AMF. The higher lime doses L3 worked better with Urea on availability soil $P$ increasing the number of AMF spores, as also with L2. Cluster analysis showed that the most influential factor was highest lime doses, were pasture type and N, P, K fertilizer source used were less influential factors on AMF spores' number under SCP improve. On the other hand, further studies may be conducted in the future to analyze the influence of soil physicochemical and biological properties on AMF populations to improve the sustainability of livestock systems at tropical zones.

Funding: This research was funded by General Direction of Research of the University of the Llanos, Villavicencio, Colombia.

Acknowledgments: The authors thank to Dalila for her help for process of AMF determination at Phytopathology Laboratory, University of the Llanos. To the General Direction of Research of the University of the Llanos, Colombia, for the economic support.

Conflicts of Interest: "The authors declare no conflict of interest". "The funders had no role in the design of the study; in the collection, analyses, or interpretation of data; in the writing of the manuscript or in the decision to publish the results".

\section{REFERENCES}

1. Fageria NK and Baligar VC. Chapter 7 Ameliorating soil acidity of tropical oxisols by liming for sustainable crop production. Adv. Agron. 2008;99:345-99.

2. Herridge DF, Peoples MB, Boddey RM. Global inputs of biological nitrogen fixation in agricultural systems. Plant Soil. 2008;311:1-18.

3. Fitter A, Helgason T, Hodge A. Nutritional exchanges in the arbuscular mycorrhizal symbiosis: Implications for sustainable agriculture. Fungal Biol Rev. 2011;25:68-72.

4. Costa N de L, Paulino VT, Lucena MAC, Schunke R, Lopes RB, Magalhães JA, Nascimento LE da S. Resposta de Pueraria phaseoloides (Benth) à adubação fosfatada em presença ou não de fungo micorrízico. Pubvet. 2012; 6: 9. Ed. 196, Art. 1315.

5. Lüscher A, Mueller-Harvey I, Soussana JF, Rees RM, Peyraud JL. Potential of legume-based grassland-livestock systems in Europe: a review. Grass Forage Sci. 2014;69(2):206-28.

6. Júnior JQO, Jesu EC, Lisboa F, Berbara RLL, Miana de Faria CS. Nitrogen-fixing bacteria and arbuscular mycorrhizal fungi in Piptadenia gonoacantha (Mart.) Macbr. Braz. J. Microbiol. 2017;48:95-100.

7. Meng L, Zhang A, Wang F, Han X, Wang D, Li S. Arbuscular mycorrhizal fungi and Rhizobium facilitate nitrogen uptake and transfer in soybean/maize intercropping system. Front. Plant Sci. 2015;13:339.

8. Adesemoye AO and Kloepper JW. Plant-microbe's interactions in enhanced fertilizer-use efficiency. Appl Microbiol Biotechnol. 2009;85:1-12.

9. Guo YJ, Ni Y, Raman H, Wilson BAL, Ash GJ, Wang AS, Li GD. Arbuscular mycorrhizal fungal diversity in perennial pastures; responses to long-term lime application. Plant Soil. 2012;351:389-403.

10. Schneider J, Filho O, Vieira SM, Alves MV. Influence of different management systems and liming on mycorrhizal arbuscular fungi in a long-term experiment. Cienc. Agrotec. 2011;35:701-9.

11. Smith SE, Facelli E, Pope S, Smith FA. Plant performance in stressful environments: interpreting new and established knowledge of the roles of arbuscular mycorrhizas. Plant Soil. 2010;326:3-20.

12. Zhong W, Gu T, Wang W, Zhang B, Lin X, Huang Q. et al. The effects of mineral fertilizer and organic manure on soil microbial community and diversity. Plant Soil. 2010;326:511-22.

13. Lin X, Feng $Y$, Zhang $Y$, Chen R, Wang R, Zhang J. et al. Long-term balanced fertilization decreases arbuscular mycorrhizal fungal diversity in an arable soil in North China revealed by 454 pyrosequencing. Environ. Sci. Technol. 2012;46:5764-71.

14. Avio L, Castaldini M, Fabiani A, Bedinic S, Sbarana C, Turrinic A, et al. Impact of nitrogen fertilization and soil tillage on arbuscular mycorrhizal fungal communities in a Mediterranean agroecosystem. Soil Biol Biochem. 2013;67:285-94.

15. Liu W, Zhang Y, Jiang S, Deng Y, Christie P, Murray PJ et al. Arbuscular mycorrhizal fungi in soil and roots respond differently to phosphorus inputs in an intensively managed calcareous agricultural soil. Sci. Rep. 2016;6:24902.

16. Gómez-Carabalí A, Rao IM, Otero JT. Influence of fertilization, season, and forage species in presence of arbuscular mycorrhizae in a degraded Andisoil of Colombia. Acta Agron. 2011;60:84-92.

17. Jaramillo DF. Introducción a la Ciencia del suelo. Medellín: Universidad Nacional de Colombia; 2002. Available from: http://www.bdigital.unal.edu.co/2242/1/70060838.2002.pdf1 
18. Cochrane TT, Salinas JG, Sánchez PA. An equation for liming acid mineral soils to compensate crop aluminum tolerance. Trop. Agric. 1980;57:133-40.

19. Guerrero, R. Fertilización de cultivos en clima cálido. Bogotá: MONOMEROS; 1988. Available from: http://www.monomeros.com/descargas/dpmanualcalido.pdf

20. Soteras F, Coutinho B, Grilli G, Pastor N, Carneiro F, Ruela F, Renison D, Megumi F, De Souza F, Becerra A. Arbuscular mycorrhizal fungal diversity in rhizosphere spores versus roots of an endangered endemic tree from Argentina: Is fungal diversity similar among forest disturbance types?. Appl Soil Ecol. 2016;98:272-273.

21. Bonfante P, Anca IA. Plants, mycorrhizal fungi, and bacteria: a network of interactions. Annu. Rev. 2009;63:36383.

22. Crespo G, González PJ, Arzola J, Morgan O. Efecto de la inoculación de hongos micorrízicos arbusculares nativos y una especie seleccionada en los pastos Brachiaria decumbens vc. Basilisk y Panicum maximum vc. Mombaza. Cuban J Agr Sci. 2010;44:307-13.

23. Spagnoletti F, Fernandez A, Tobar N, Chiocchio V. Las micorrizas arbusculares y Rhizobium: una simbiosis dual de interés. Rev Argent Microbiol. 2013;45:131-2.

24. Martin GM and Rivera R. Influencia de la inoculación micorrízica en los abonos verdes. Efecto sobre el cultivo principal. Estudio de caso: el maíz. Cultivos tropicales. 2015;36:34-50.

25. Richardson AE, Barea JM, McNeill AM, Prigent-Combaret C. Acquisition of phosphorus and nitrogen in the rhizosphere and plant growth promotion by microorganisms. Plant Soil. 2009;321:305-39.

26. González P, Pérez P, Medina N, Medina G, Ramírez J, Arzola J. Co-inoculation of rhizobium strains and one of arbuscular mycorrhizial fungi (Glomus cubense) and its effect on kudzu (Pueraria phaseoloides). Cuban J Agr Sci. 2012;46:331-4.

27. Fabrice CES, Filho CVS, Pinto MF, Perri CHV, Cecato U, Mateus GP. Soil chemical properties, organic reserves and root system of a degraded pasture associated introduction of legume. Semina: Cienc. Agrar. 2014;35:172130.

28. Tajini F, Trabelsi M, Drevon J. Co-inoculation with Glomus intraradices and Rhizobium tropici CIAT899 increases $\mathrm{P}$ use efficiency for N2 fixation in the common bean (Phaseolus vulgaris L.) under P deficiency in hydroaeroponic culture. Symbiosis. 2011; 53: 123-9.

29. Frankow-Lindberg BE and Dahlin AS. N2 fixation, $\mathrm{N}$ transfer, and yield in grassland communities including a deeprooted legume or non-legume species. Plant Soil. 2013; 370: 567-81.

30. Silva A, Garay S, Gómez A. Impacto de Alnus acuminata Kunth en los flujos de $\mathrm{N}_{2} \mathrm{O}$ y calidad del pasto Pennisetum clandestinum Hochst. ex Chiov. Colomb. Forest. 2018;21:47-57.

31. Van der Heijden MGA, Martin FM, Selosse MA, Sanders IR. Mycorrhizal ecology and evolution: the past, the present, and the future. New Phytol. 2015;205:1406-23.

32. Wu ZP, Mcgrouther K, Huang JD, Wu PB, Wu WD, Wang HL Decomposition and the contribution of glomalinrelated soil protein (GRSP) in heavy metal sequestration: field experiment. Soil Biol Biochem. 2014;68:283-90.

33. Seguel A, Cumming J, Klugh-Stewart K, Cornejo P, Borie F. The role of arbuscular mycorrhizas in decreasing aluminium phytotocity in acid soils: a review. Mycorrhiza. 2013;23:167-83.

34. Longo RM, Ribeiro Al, Melo WJ. Uso da adubação verde na recuperação de solos degradados por mineração na floresta amazônica. Bragantia. 2011;70:139-46.

35. Delgado H, Navas GE, Salamanca CR, Chacón A. Barbechos mejorados con leguminosas: una promisoria alternativa agroecológica para el manejo alelopático de malezas y mejoramiento del cultivo de arroz y maíz en los Llanos de Colombia. Agron. Colomb. 2009;27:227-35.

36. Pérez $A$ and Fuentes J. Regresión logística en la evaluación de la esporulación de micorrizas en pasto Bothriochloa pertusa (L) A. Camus. RECIA. 2009;1:1-18.

37. Pérez CA, Vertel MM. Evaluación de la colonización de micorrizas arbusculares en pasto Bothriochloa pertusa (L) A. Camus. Revista MVZ Córdoba. 2010;15:2165-74.

38. Parra AS, de Figueiredo EB, de Bordonal, RO. et al. Greenhouse gas emissions in conversion from extensive pasture to other agricultural systems in the Andean region of Colombia. Environ Dev Sustain. 2019;21:249.

39. Szanser M, Kusińska A, Kisiel M, Sieminiak D. Possibility of using diverse plant litter in soil restoration processes. Procedia Environ. Sci. 2011;9:169-73.

40. Bender SF, Plantenga F, Neftel A, Jocher M, Oberholzer HR, Köhl L. et al. Symbiotic relationships between soil fungi and plants reduce $\mathrm{N}_{2} \mathrm{O}$ emissions from soil. ISME J. 2014;8:1336-45.

41. Hempel S, Renker C, Buscot F. Differences in the species composition of arbuscular mycorrhizal fungi in spore, root and soil communities in a grassland ecosystem. Environ Microbiol. 2007;9:1930-8. 
42. Schmidt B, Domonkos $M$, Sumãlan R, Biró R. Suppression of arbuscular mycorrhiza's development by high concentrations of phosphorous at Tagetes patula L. Agric. Sci. Res. J. 2010;42:156-62.

43. Nouri E, Breuillin-Sessoms F, Feller U, Reinhardt D. Phosphorus and nitrogen regulate arbuscular mycorrhizal symbiosis in Petunia hybrida. PLoS ONE. 2014; 9: e90841.

(C) 2021 by the authors. Submitted for possible open access publication under the terms and conditions of the Creative Commons Attribution (CC BY NC) license (https://creativecommons.org/licenses/by-nc/4.0/). 